\title{
Assignment of genes for interleukin-8 receptors (IL8R) A and B to human chromosome band $2 q 35$
}

\author{
A. Lloyd, ${ }^{1,3}$ W. Modi, ${ }^{3}$ H. Sprenger, ${ }^{1}$ S. Cevario, ${ }^{2}$ J. Oppenheim, ${ }^{1}$ and \\ D. Kelvin ${ }^{1}$ \\ ' Laboratory of Molecular Immunorcgulation. Biological Response Modifiers Program. ${ }^{2}$ Laboratory of Viral Carcinogenesis. \\ National Cancer Institute, and ${ }^{3}$ Program Resources/Dyncorp Inc., Frederick. MD (USA)
}

\begin{abstract}
The human genes encoding the interleukin 8 receptors type $A$ and $B$ were assigned to chromosome 2 by polymerase chain reaction amplification and by Southern analysis
\end{abstract}

of a panel of human $\times$ rodent somatic cell hybrid DNAs. The IL8R genes were further localized by in situ hybridization to band $2 \mathrm{q} 35$.
The chemoattractant molecules, interleukin-8 (IL8), the anaphylatoxin C5a, and the bacterially derived $\mathrm{N}$-formyl peptides are important mediators of inflammation. Interaction of these ligands with specific receptors on phagocytic cells stimulates directed migration (chemotaxis) and the release of lysosomal granule contents. The chemoattractant receptors constitute a newly recognized subgroup of the rhodopsin superfamily of G-protein-coupled receptors (Boulay et al., 1990). The rhodopsin family is further characterized by a seven-transmembrane domain structure and includes receptors for the visual pigment opsin, the adrenergic hormones, several neurotransmitter molecules (including acetylcholine, substance $\mathrm{K}$, substance $\mathrm{P}$, and serotonin), and the olfactory receptor (Dohlman et al., 1991).

Receptors for several chemoattractant molecules have been molecularly cloned (Boulay et al., 1990; Gerard and Gerard, 1991; Holmes et al., 1991; Murphy and Tiffany, 1991), including two closely homologous cDNAs encoding receptors for IL8, designated here as type IL8RA and IL8RB, isolated from HL60

A.L. is supported by a postdoctoral fellowship from the National Health and Medical Research Council of Australia. This project has been funded at least in part with Federal funds from the US Department of Health and Human Resources under contract No. N01-C0-74102 with Program Resources. Inc. The content of this publication does not necessarily refect the views or policies of the Department of Health and Human Resources, nor does mention of trade names, commercial products, or organizations imply endorsement by the US government.

Received 28 August 1992; revision accepted 3 March 1993.

Request reprints from Dr. Andrew R. Lloyd, Laboratory of Molecular Immunoregulation, Building 560, Rm 31-19. National Cancer Institute. Frederick, MD 21702 (USA): telephone: $301-846-1347$; fax: 301-846-1673. myelomonocytic cells and neutrophils, respectively. The IL8R cDNAs share $77 \%$ amino acid identity, including continuous identical regions of 105 and 64 amino acids. In this study we used Southern hybridization techniques with DNA isolated from a panel of human $\times$ rodent somatic cell hybrids and fluorescent in situ hybridization to determine the chromosomal localization of the IL8RA gene. In addition, the IL8RB gene was localized by polymerase chain reaction (PCR) amplification of the human gene from the hybrid DNA panel, as well as by fluorescent in situ hybridization.

\section{Materials and methods}

Degenerate oligonucleotide primers were prepared from homologous regions in the sixth and seventh transmembrane domains of the published sequences of the human $N$-formyl peptide (Boulay et al., 1990) and C5a receptors (Gerard and Gerard. 1991) and the rabbit IL8 receptor (Thomas et al.. 1990). These primers were used in the PCR to amplify known and novel cDNAs from various RNA templates. A 155-bp cDNA encoding an apparently novel sequence with $55 \%$ homology to the published receptors was isolated. This $\mathrm{CDNA}$ was used to screen a custom-made plasmid cDNA library in the pCDM8 vector which had been prepared from $U 937$ myelomonocytic cellular poly-A RNA (Invitrogen. San Diego. CA). A 1.552-bp clone was isolated, sequenced, and found to be identical to the recently published IL8RA clone. A 552-bp /Thal-/lindIII fragment of this clone (nucleotides 698-1,250, bearing only $58 \%$ homology with the related region within the published sequence of IL8RB CDNA) was used for Southern analysis of human $\times$ rodent somatic cell hybrid DNA. These were SST-digested genomic DNAs from a panel of 16 mouse $\times$ human and 29 hamster $\times$ human hybrid DNAs. as well as human, mouse, and hamster control DNA. Hybridization was performed at $42^{\circ} \mathrm{C}$ in a mixture containing $50 \%$ formamide (Hybrisol I. Oncor, Gaithersberg. MD). The blots were washed at 42.48 , and $55^{\circ} \mathrm{C}$ in $2 \times \mathrm{SSC}$. $0.1 \%$ SDS. 
The IL8RB gene was localized by PCR amplification from the somatic hybrid panel, followed by agarose gel electrophoresis. A 1,050-bp sequence was amplified with two synthetic oligonucleotides (5'-TTGCTGAAACTGAAGAA-3' and 5'-GACATTGACAGACGAAGA-3') from either cDNA or human genomic templates, suggesting that the open reading frame of the IL8RB gene is uninterrupted by an intronic sequence. The PCR products were further verified by Southern blotting and hybridization with a 245-bp Accl fragment (nucleotides 1-245) of the IL8RB cDNA, a region having $60 \%$ nucleotide homology with the comparable region of the IL8RA CDNA. Hamster and mouse genomic DNA templates provided no significant bands on gel electrophoresis or Southern hybridization. Positive samples in the hybrid panel were confirmed in a second round of PCR.

The type A and B IL8R cDNAs were used to screen a human genomic library in $\lambda$-DASH (Stratagene, San Diego. CA), from which genomic clones were isolated. A 9.kb EcoRI fragment of the IL8RA clone containing the

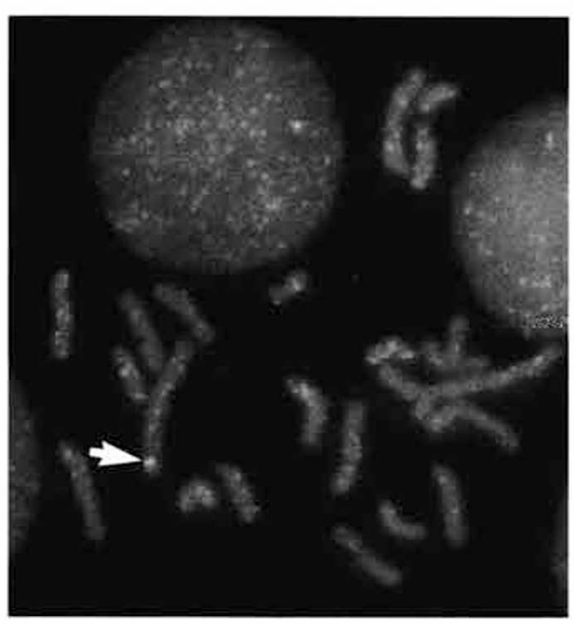

Fig. 1. Partial human metaphase following fluorescence in situ hybridization with an IL8RA genomic fragment as the probe; arrow indicates position of hybridization signal at chromosome band $2 \mathrm{q} 35$. The IL8R B gene colocalized to the same band in a similar experiment (data not shown). complete open reading frame in a single exon was used as a probe for in situ hybridization, utilizing a standard fluorescent technique (Tory et al.. 1992). Two overlapping fragments ( $15 \mathrm{~kb}$ ) resulting from $S \mathrm{StI}$ and / HindlI digests of the IL8RB genomic clone were used similarly for in situ hybridization. In brief, metaphase chromosomes were prepared from PHA-stimulated peripheral blood leukocytes. Probe DNA was labeled with biotin-1 1-dUTP using nick translation. Hybridization was performed at $37^{\circ} \mathrm{C}$ for $16 \mathrm{~h}$, followed by washes at $40^{\circ} \mathrm{C}$ in a solution containing $50 \%$ formamide in $2 \times$ SSC.

\section{Results and discussion}

In the IL8RA Southern blot experiment, the labeled probe recognized only human genes with two detectable SST fragments ( 2.3 and $2.0 \mathrm{~kb})$. The IL8RA bands exhibited the least discordance $(8 \%)$ with chromosome $2\left(\chi^{2}\right.$ test, $\left.P=0.0001\right)$. All other chromosomes were at least $17 \%$ discordant (Table I). PCR amplification for IL8RB produced hybridization-positive bands of the predicted size in $7 / 45$ hybrids. The analysis also mapped IL8RB to chromosome 2 with a discordancy of $7 \%$ $(P<0.001)$.

Forty-two metaphase cells were examined following in situ hybridization with the IL8RA probe. Specific hybridization was noted at band $2 \mathrm{q} 35$ in 22 cells (Fig. 1), and no significant background was observed at any other chromosomal sites. The IL8RB probe also hybidized specifically to 2q35 in 44/55 metaphase cells.

Our results confirm and refine the recent localization of the IL8RA and IL8RB genes to $2 q 34 \rightarrow$ q35 (Ahuja et al., 1992). The high degree of amino acid homology and co-localization of the genes for the IL8 receptors suggest that these genes may have arisen by duplication. Further studies examining the genomic structure of the IL $8 \mathrm{R}$ genes may clarify this relationship. The IL8 receptors are co-expressed on polymorphonuclear neutrophils and, because of their genomic proximity, may share common regulatory elements.

Table I. Segregation of human IL-8 receptor genes in human $\times$ rodent somatic cell hybrids

\begin{tabular}{|c|c|c|c|c|c|c|c|c|c|c|c|c|c|c|c|c|c|c|c|c|c|c|c|}
\hline \multirow{2}{*}{$\begin{array}{l}\text { Human gene/ } \\
\text { chromosome }\end{array}$} & \multicolumn{23}{|c|}{ Human chromosome } \\
\hline & I & 2 & 3 & 4 & 5 & 6 & 7 & 8 & 9 & 10 & 11 & 12 & 13 & 14 & 15 & 16 & 17 & 18 & 19 & 20 & 21 & 22 & $\mathrm{x}$ \\
\hline \multicolumn{24}{|l|}{ Type II IL8R² } \\
\hline$+1+$ & 3 & 4 & 4 & 5 & 2 & 6 & 4 & 5 & 4 & 3 & 6 & 5 & 4 & 4 & 3 & 4 & 1 & 7 & 4 & 0 & 4 & 4 & 9 \\
\hline$+1-$ & 6 & 3 & 5 & 4 & 7 & 3 & 5 & 4 & 4 & 6 & 3 & 4 & 5 & 3 & 4 & 4 & 7 & 2 & 5 & 7 & 4 & 5 & 0 \\
\hline$-1+$ & 1 & 0 & 8 & 11 & 2 & 7 & 5 & 6 & 5 & 4 & 13 & 3 & 7 & 14 & 7 & 5 & 1 & 9 & 3 & 9 & 11 & 7 & 29 \\
\hline$-1-$ & 31 & 33 & 25 & 21 & 30 & 25 & 25 & 27 & 28 & 26 & 20 & 29 & 22 & 17 & 26 & 27 & 31 & 23 & 28 & 23 & 19 & 25 & 3 \\
\hline $\begin{array}{l}\text { Percent } \\
\text { discordancy }\end{array}$ & 17 & 8 & 31 & 37 & 22 & 24 & 26 & 24 & 22 & 26 & 38 & 17 & 32 & 45 & 28 & 23 & 20 & 27 & 20 & 41 & 40 & 29 & 71 \\
\hline \multicolumn{24}{|l|}{ Type I IL8R } \\
\hline$+1+$ & 3 & 3 & 4 & 4 & 2 & 3 & 3 & 3 & 3 & 3 & 6 & 4 & 4 & 4 & 1 & 2 & 1 & 4 & 3 & 0 & 4 & 2 & 7 \\
\hline$+1-$ & 4 & 2 & 3 & 3 & 5 & 4 & 4 & 4 & 4 & 4 & 1 & 3 & 3 & 3 & 4 & 4 & 5 & 3 & 4 & 6 & 3 & 5 & 0 \\
\hline$-1+$ & 1 & 1 & 8 & 13 & 2 & 11 & 6 & 8 & 7 & 4 & 13 & 5 & 8 & 15 & 10 & 6 & 1 & 12 & 4 & 11 & 12 & 10 & 34 \\
\hline$-1-$ & 36 & 37 & 30 & 24 & 35 & 26 & 29 & 29 & 31 & 31 & 25 & 31 & 25 & 21 & 28 & 30 & 36 & 25 & 32 & 26 & 23 & 27 & 3 \\
\hline $\begin{array}{l}\text { Percent } \\
\text { discordancy }\end{array}$ & 11 & 7 & 24 & 36 & 16 & 34 & 24 & 27 & 24 & 19 & 31 & 19 & 28 & 42 & 33 & 24 & 14 & 34 & 19 & 40 & 36 & 34 & 77 \\
\hline
\end{tabular}

- Chromosome assignment by Southern hybridization.

Chromosome assignment by PCR amplification. 
The genes for several other members of the rhodopsin superfamily of receptors have been mapped to chromosome 2 , including the receptor-like 1 alpha-2-adrenergic locus (ADRA 2L1) on 2q and the luteinizing hormone/choriogonadotropin receptor gene (LHCGR) at band 2p21 (Spurr and White. 1991). Of particular interest is the recent localization of the gene for the human receptor for vasoactive intestinal peptide (VIPRI) to band 2q37 (Libert et al., 1991). This gene shares $30 \%$ amino acid identity with the IL 8 receptors, is expressed on $\mathrm{T}$ and $\mathrm{B}$ cells (Finch et al., 1989), and mediates immunological, as well as neuroendocrine, functions (Goetzl et al., 1990). The VIPRI gene may therefore be an intermediate in the evolution of the chemoattractant cytokine receptors from the rhodopsin superfamily. In contrast. the $\mathrm{N}$-formyl peptide receptor gene (FPRI) and two closely related genes (FPRL1 and FPRL2; Murphy et al., 1992) and the C5a receptor gene (C5AR; Bao et al., 1992) have all recently been localized to chromosome 19. The $N$-formyl peptide and C5a receptors share $35 \%$ amino acid identity with each other and only approximately $23 \%$ homology with the IL8 receptors. These receptor clusters (IL8RA and IL8RB, on the one hand, and FPRI, FPRL1, FPRL2, and C5AR, on the other) may represent distinct evolutionary subfamilies within the chemoattractant receptor members of the rhodopsin superfamily.

\section{References}

Ahuja SK, Ozcelik T. Milatovitch A, Francke U, Murphy PM: Molecular evolution of the human interleukin-8 receptor gene cluster. Nature Genet 2:31 36 (1992).

Bao L. Gerard NP. Eddy RL. Shows TB. Gerard C: Mapping of genes for the human C5a receptor (C5AR), human FMLP receptor (FPR), and two FMLP receptor homologue orphan receptors (FPRHI, FPRH2) to chromosome 19. Genomics 13:437-440 (1992)

Boulay F, Tardif M, Brouchon L. Vignais P: The human $\mathrm{V}$-formylpeptidc receptor: characterization of two cDNA isolates and evidence for a new subfamily of G-protein-coupled receptors. Biochemistry 29:111123-111133(1990).

Dohlman HG. Thomer H. Caron MG. Lefkowitz RJ: Model systems for the study of seven-transmembrane-segment receptors. A Rev Biochem 60:653688 (1991).
Finch RJ. Sreedharan SP. Goetzl EJ: High-affinity receptors for vasoactive intestinal peptide on human myeloma cells. J Immunol 142:1977-1981 (1989).

Gerard NP, Gerard C: The chemotactic receptor for human CSa anaphylatoxin. Nature 349:614-617 (1991).

Goetzl EJ. Adelman DC. Sreedharan SP: Neuroimmunology, in Dixon FJ, Austen KF, Hood L, Uhr JW (eds): Advances in Immunology, pp 161-190 (Academic Press, New York 1990).

Holmes WE. Lee J, Kuang WJ, Rice GC. Wood WI: Structure and functional expression of a human interleukin-8 receptor. Science 253:1278-1280 (1991).

Liber F. Passage E, Parmentier M. Simons M-J, Vassart G. Mattei M-G: Chromosomal mapping of Al and $A 2$ adenosine receptors. VIP receptor and a new subtype of serotonin receptor. Genomics 11:225-227(1991).
Murphy PM, Ozcelik T, Kenney RT. Tiffany HL. McDermott D, Francke U: A structural homologue of the $N$-formyl peptide receptor: characterization and chromosome mapping of a peptide chemoat. tractant receptor family. J biol Chem 267:76377643 i1992).

Murphy PM, Tiffany HL: Cloning and complementary DNA encoding a functional human interleukin-8 receptor. Science 253:1280-1283 (1991).

Thomas KM, Pyun HY, Navarro J: Molecular cloning of the Met-Leu-Phe receptor from neutrophils. J biol Chem 265:20061-20064 (1990).

Tory K, Latif F, Modi W, Schmidt L, Wei HM, Li H. Cobler P, Orcutt ML, Delisio J, Geil L, Zbar B, Lerman MI: A genetic linkage map of 96 loci on the shor arm of human chromosome 3. Genomics 1 3:275-286 (1992).

Spurr NK. White R: Report of the committee on the genetic constitution of chromosome 2. Eleventh International Workshop on Human Gene Mapping. Cytogenet Cell Genet 58:142-169 (1991). 